\title{
Prospect evaluation and hydrocarbon potential assessment: the Lower Eocene Facha non-clastic reservoirs, Hakim Oil Field (NC74A), Sirte basin, Libya - a case study
}

\author{
Mohamed A. Kassab ${ }^{1}$ - Ali El-Said Abbas ${ }^{2} \cdot$ Mostafa A. Teama $^{2} \cdot$ Musa A. S. Khalifa $^{3}$
}

Received: 8 November 2018 / Accepted: 4 September 2019 / Published online: 24 September 2019

(c) The Author(s) 2019

\begin{abstract}
Petrophysical assessment of Facha Formation based on log data of six wells A1, A3, A4, A5, A8 and A13 recorded over the entire reservoir interval was established. Hakim Oil Field produces from the Lower Eocene Facha reservoir, which is located at the western side of Sirte basin. Limestone, dolostone and dolomitic limestone are the main lithologies of the Facha reservoir. This lithology is defined by neutron porosity-density cross-plot. Noteworthily, limestone increases in the lowermost intervals of the reservoir. Structurally, the field is traversed by three northwest-southeast faults. The shale of the Upper Cretaceous Sirte Formation is thought to be the source rock of the Facha Formation, whereas the seals are the limestone and anhydrite of the Lower Eocene Gir Formation. In this study, the Facha reservoir's cutoff values were obtained from the cross-plots of the calculated shale volume, porosity and water saturation values accompanied with gamma ray log data and were set as $20 \%, 10 \%$ and $70 \%$, respectively. Isoparametric maps for the thickness variation of net pay, average porosity, shale volume and water saturation were prepared, and the authors found out that the Facha Formation has promising reservoir characteristics in the area of study; a prospective region for oil accumulation trends is in the north and south of the study area.
\end{abstract}

Keywords Well $\log \cdot$ Petrophysical parameter $\cdot$ Lower Eocene $\cdot$ Hakim Oil Field $\cdot$ Sirte basin $\cdot$ Libya

\section{Introduction}

The Sirte basin covers an area of about $600,000 \mathrm{~km}^{2}$ with a sedimentary succession of about $7500 \mathrm{~m}$ (Hallet 2002). The basin has the largest petroleum reserves where it has about 36.7 BB of oil and 37.7 TCF of gas (Ahlbrandt 2001).

This study focuses around the Hakim Oil Field, where the main pay is the Facha reservoir. The Hakim Field located at the southwestern part of Sirte basin in concession NC-74A, approximately $580 \mathrm{~km}$ southeast of Tripoli, lies between latitudes of $28^{\circ} 40^{\prime}$ and $29^{\circ} 00^{\prime} \mathrm{N}$ and longitudes of $17^{\circ} 21^{\prime}$ and $18^{\circ} 00^{\prime} \mathrm{E}$, (Fig. 1).

Mohamed A. Kassab

mkassab68@yahoo.com

1 Egyptian Petroleum Research Institute (EPRI), Nasr City, Egypt

2 Faculty of Petroleum and Mining Engineering, Suez University, Suez, Egypt

3 Mellitah Oil \& Gas B. V. Libyan Branch, Tripoli, Libya
The first well was discovered and drilled in 1978 at the southwestern side of Sirte basin from the Upper Facha dolomite with $20 \mathrm{MM}$ barrels of recoverable oil (Geological Review of Hakim 1981).

The lithology analysis included in this study depends on cross-plots by using logging data of six oil wells (A1, A3, A4, A5, A8 and A13). In addition, the petrophysical parameters are evaluated by estimating content of shale, storage capacity (porosity), water saturation and net pay thickness. The prospect evaluation of the study area is achieved by constructing isoparametric maps and estimating the prospective regions for hydrocarbon accumulations.

\section{Geological and structural setting}

The studied basin's tectonic features are represented from east to west by Maradah trough, Ajdabiya trough, Hameimat trough, Sarir trough, Zallah trough, Dur Al-Abd trough and finally Hun graben. They are separated by Amal platform, Rakb high, Zaltan platform, Al-Bayda platform and finally Waddan uplift (Fig. 2). These structural features have great 


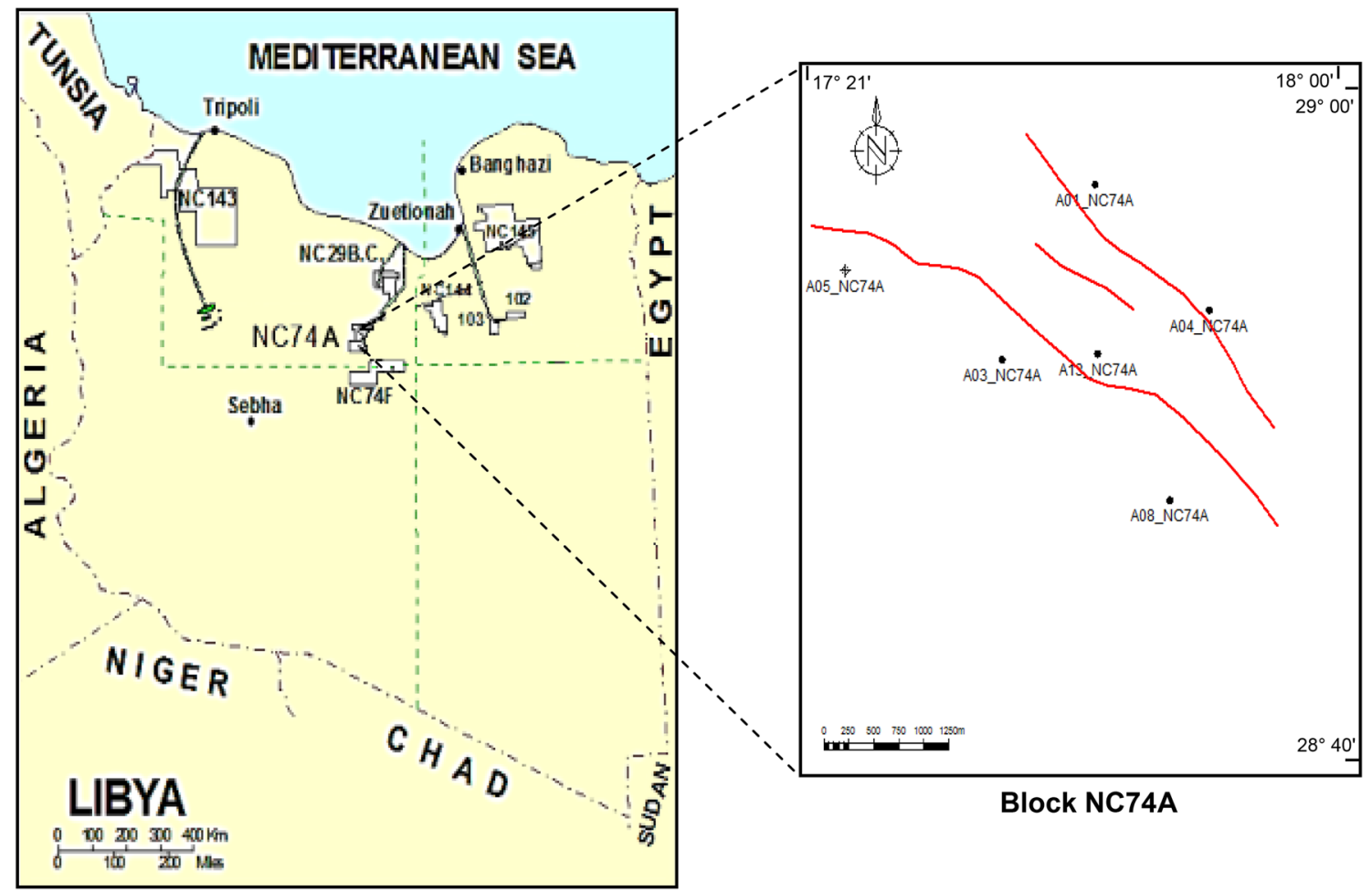

Fig. 1 Location map of Hakim Field

effect on the migration of hydrocarbon from the troughs along the block basement faults to the platforms where most fields are situated.

\section{Structural framework of the study area}

It appears that the structural evolution of the study area (Hakim Field) was controlled by the regional tectonic activity that occurred on the western part of Sirte basin, where most of the area is divided by major NW to SE normal faulting pattern (Fig. 2). The fault-related anticline and syncline can be considered later as a potential trap for hydrocarbons in study area.

The Sirte basin formed due to the extension of crust during the Early Cretaceous-Tertiary leading to the subsidence and formation of the Sirte arch (Ahlbrandt 2001 and Van der Meer 1993). Four main phases of uplifting and subsidence are encountered within the basin as the following: (Abadi 2002).

- Phase I During Late Jurassic to the Early Cretaceous and represents the falling in the southeast of the studied basin over an E-W structural trend.

- Phase II Represents the major and rapid falling along the NW-SE structural trend during the Late Cretaceous time, when the main significant hydrocarbon source rocks deposited. In addition, a marginal marine was developed south of the basin which continued from Cenomanian until the Coniacian.

- Phase III This phase, according to Guiraud and Bosworth 1997 , represents the development of shallow marine in southern Libya during the Paleocene times with active subsidence affecting most of the troughs within Sirte basin. As a result of this subsidence, the basin was affected by a regression through the Lower Eocene causing deposition of evaporites of the Gir Formation south and west of the basin.

- Phase IV is concerning the Middle Eocene until the current day and was caused by sediments load and thermal relaxation within the basin. The Late Eocene was introduced by marine deposits due to a transgression event developed in the Lower Oligocene. In this period, subsidence was active along NW structure in the Ajdabiya trough. Regression event occurred in Post-Middle Miocene times due to rapid fall in the level of the Mediterranean, depositing continental facies.

These tectonic phases had an important effect on the lithostratigraphic units within the basin.

\section{Lithostratigraphy}

After the opening of the basin, sedimentary sequences varying from continental to near shore and marine 


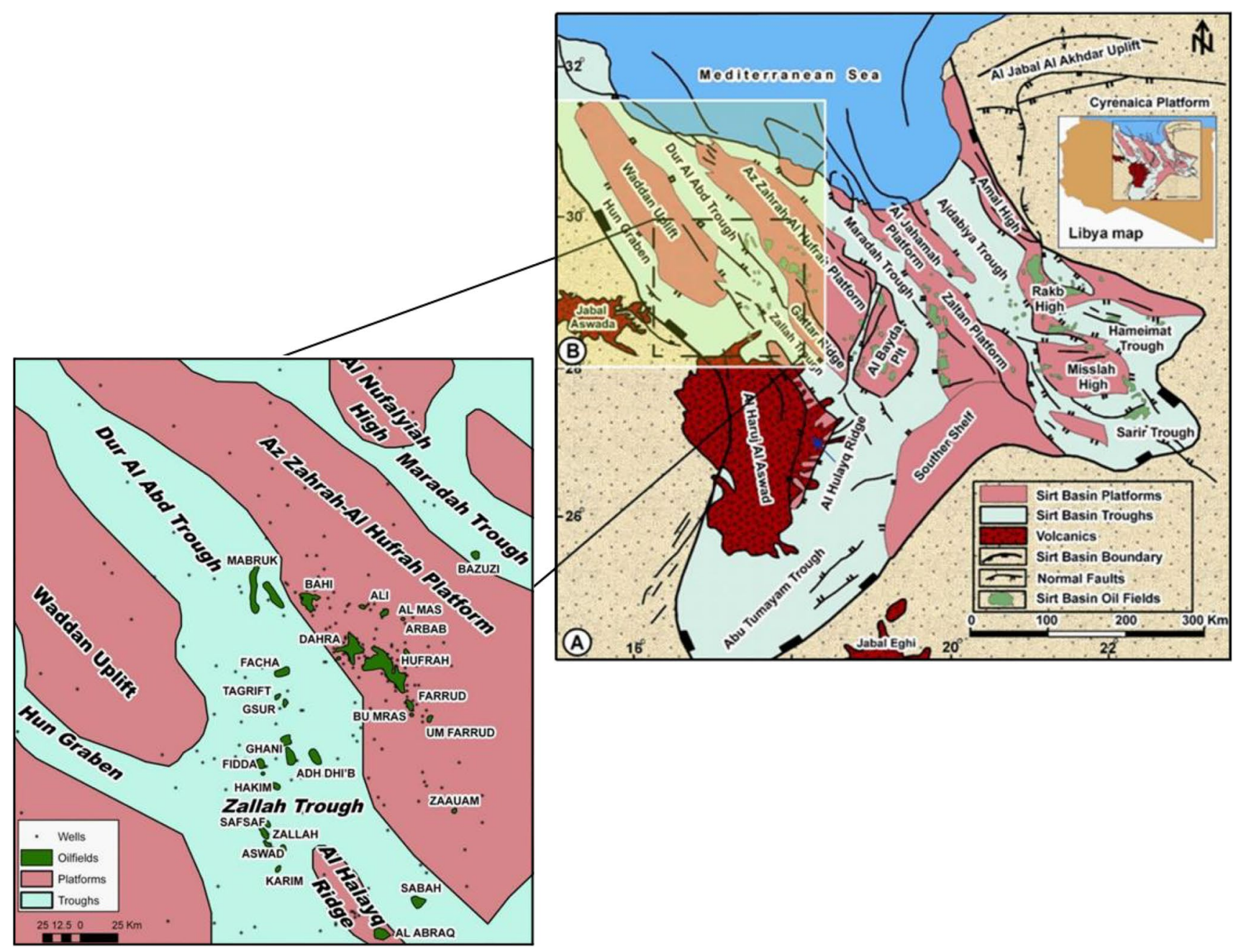

Fig. 2 Generalized tectonic map of the Sirte basin as located in the north-central Libya map (modified after Abadi 2002) showing the major structural elements and oil and gas fields. The dashed box marks the Zallah trough area with its structural domains referred to in the text. Inset illustrates the Libya map

\section{Petroleum system}

The structural conditions of the study area are represented by fold and fault systems which form the trapping pattern. In more detail, fault-related NW-SE anticlines is considered as a main hydrocarbon trap in the Hakim Field (Geological Review of Hakim 1981).

\section{Source rocks}

The published studies have concluded that the main source rock in the studied area is the Shale of Sirte Formation (Parsons et al. 1980; Gumati and Schamel 1988; Montgomery 1994; El-Alami et al. 1989; Ghori and Mohammed 1996;

tion is 308 feet (Barr and Weeger 1972). 
Fig. 3 General stratigraphic column of Sirte basin. Modified after Aboglila and Elkhalgi (2013)

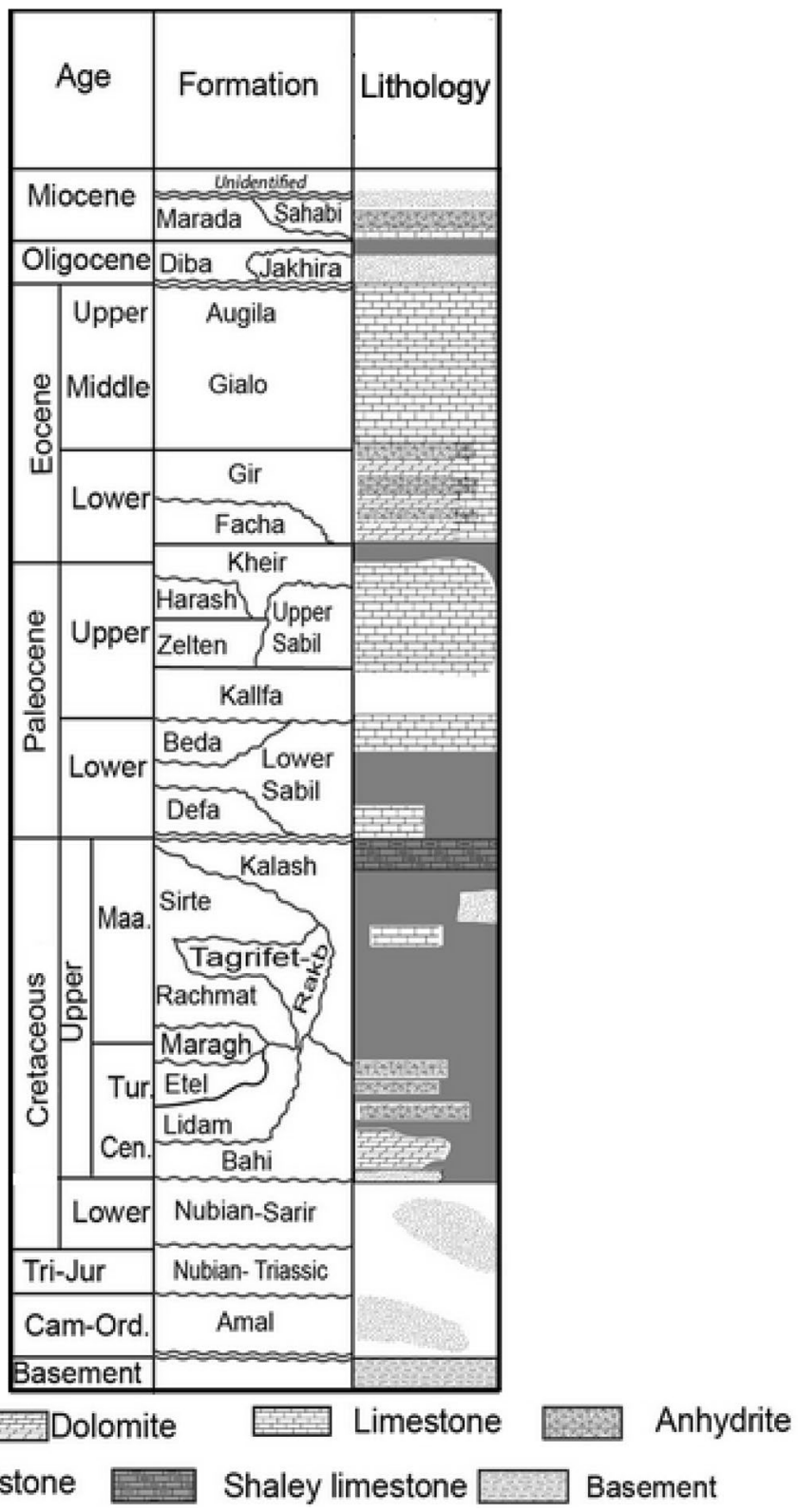

Macgregor and Moody 1998; Ambrose 2000; Burwood 1997). The thickness of these Shale beds reaches up to $900 \mathrm{~m}$ in the troughs and produces oil at burial depths from 2700 to $3400 \mathrm{~m}$ (Futyan and Jawzi 1996).

\section{Reservoirs}

The tectonic events in the Sirte basin are of great effect on the reservoir distribution and quality. Most of the reservoirs from Precambrian to Eocene are charged along faults (Harding 1984).

The Tertiary carbonate reservoirs and the Pre-Tertiary clastic reservoirs contain 42 and $58 \%$ of the petroleum volume, respectively (Harding 1984). These reservoir rocks of Facha Formation are characterized by high porosity and permeability. The low porosity could be compensated by joints and fractures.

\section{Sealing}

The reliable seals for the Facha Formation are represented by the anhydrite and limestone, which belongs to Gir Formation. The limestone texture ranges between fine to coarse crystalline, nodular and sub-banded (Barr and Weeger 1972). 


\section{Data and methodology}

The reservoir hydrocarbon potential of the Facha Formation was assessed in six drilled wells (A1, A3, A4, A5, A8 and A13), depending on lithological and petrophysical analyses. The logging data cross-plot of the neutron porosity versus bulk density were utilized in this study, for lithological determination of the Facha Formation.

The logging data for the studied reservoir comprising true resistivity, neutron porosity and bulk density were collected and digitized. The authors utilized schlumberger Interactive petrophysics software (v3.6) in this study, for borehole environmental calibration and interpretation. The removal of the flush effect on shale section was applied.

The amount of shale content $\left(V_{\mathrm{sh}}\right)$ in a reservoir is the wet shale volume per unit reservoir volume. Determination of shale content is very important as the percentage of shale in the reservoir has a large impact on the log interpretation and hence reserves estimation and hydrocarbon production (Asquith 1982). The clay minerals affect reservoir porosity, water saturation and permeability. Shale content might be worked out utilizing an assortment of petrophysical records, for example, gamma ray, neutron porosity.

Archie's equation (Archie 1942) is the fundamental process for all $S w$ estimation. Water saturation $\left(S_{\mathrm{w}}\right)$ often specified from the resistivity logs and porosity.

\section{Results and discussion}

\section{Lithological interpretation using cross-plots}

Petrophysical analysis through conventional cross-plots is the key to relate two groups. Logs were carefully edited to compensate for washouts, cycle skipping, environmental corrections and any other problems. Therefore, through this section, we will present the main cross-plots which are used for lithological analysis of the Facha reservoir.

\section{Neutron porosity $\left(\emptyset_{\mathrm{N}}\right)$ versus bulk density $\left(\rho_{\mathrm{b}}\right)$ cross-plot}

Neutron porosity $\left(\varnothing_{\mathrm{N}}\right)$ versus bulk density $\left(\rho_{\mathrm{b}}\right)$ cross-plot is a common technique and quick step to know the lithology. The lithology of Facha reservoir is considered as dolomitic limestone with anhydrite interbeds (high density) at the upper part of the reservoir as indicated by the blue dotes. The lithology in all the studied wells varies from calcareous dolostone in A1 (Fig. 4), A5 and A13 (Fig. 5) wells with an increase in clay content in A1 and A5 wells, to limestone in A3 well with slightly increase in clay content (Fig. 6), to dolostone in A4 well with an increase in clay content (Fig. 7), and to dolomitic limestone in A8 well with less clay content (Fig. 8). The Facha reservoir in all wells includes few anhydrite interbeds.

It is noteworthy that the limestone increases within the lower interval of the Facha reservoir.

\section{Litho-saturation log plot}

The petrophysical characteristics deduced from the process of well $\log$ analysis are generally varied vertically through litho-saturation log plots and horizontally through isoparametric maps (El-Khadragy et al. 2017).

Gamma ray, density, acoustic, neutron porosity and true resistivity logs were adapted to evaluate the entire reservoir section. From the interpreted litho-saturation log plots, it is clear that the structural settings of the study area may play an important role in change of pay thickness of the Facha reservoir and its effective porosity, rather than change in lithology. A1 and A3 wells illustrate high and good hydrocarbon content (Fig. 9), whereas A5 and A13 wells, which
Fig. 4 Neutron porosity $\left(\emptyset_{\mathrm{N}}\right)$ versus bulk density $\left(\rho_{\mathrm{b}}\right)$ crossplot of A1 well

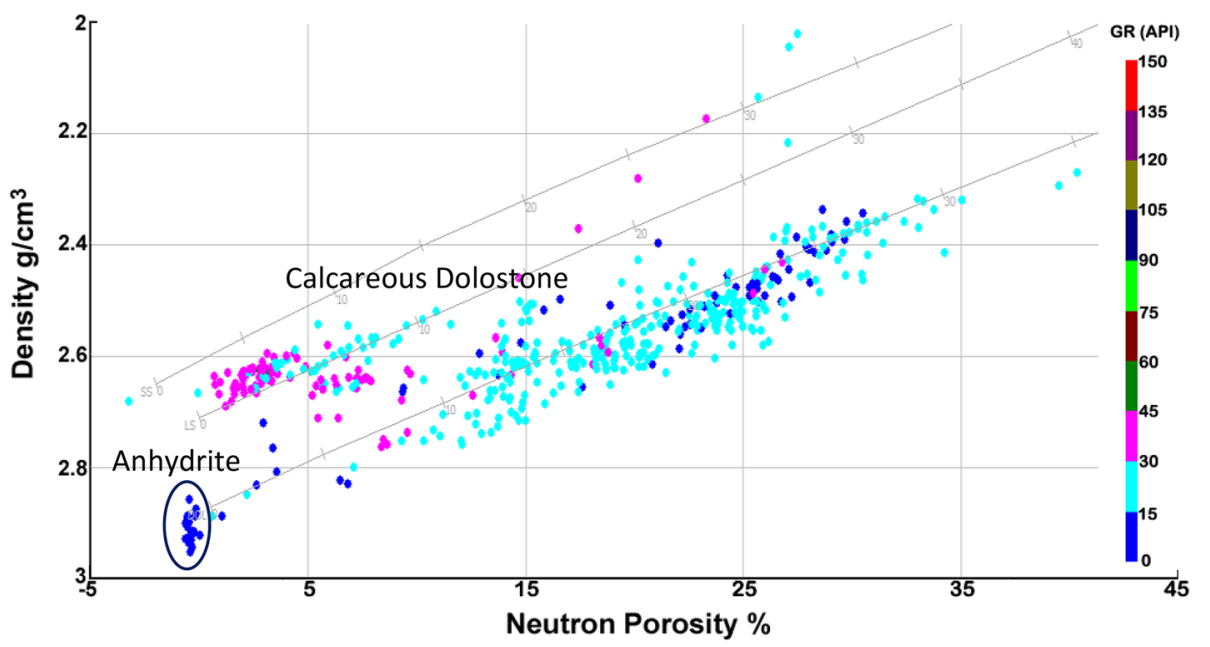

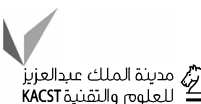
Springer 
Fig. 5 Neutron porosity $\left(\emptyset_{\mathrm{N}}\right)$ versus bulk density $\left(\rho_{\mathrm{b}}\right)$ crossplot of A13 well

Fig. 6 Neutron porosity $\left(\varnothing_{\mathrm{N}}\right)$ versus bulk density $\left(\rho_{\mathrm{b}}\right)$ crossplot of A3 well

Fig. 7 Neutron porosity $\left(\emptyset_{N}\right)$ versus bulk density $\left(\rho_{\mathrm{b}}\right)$ crossplot of A4 well
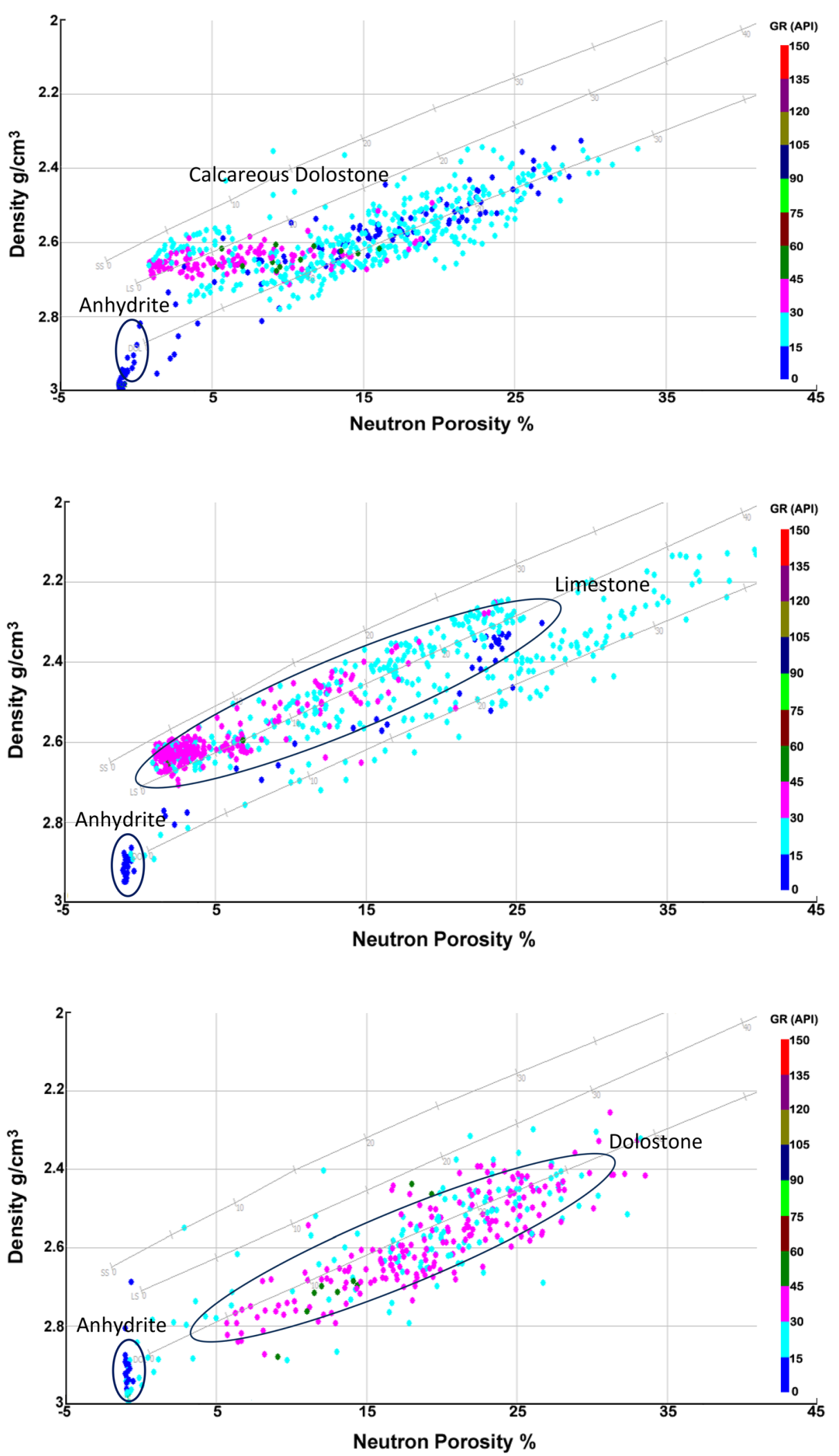
Fig. 8 Neutron porosity $\left(\emptyset_{\mathrm{N}}\right)$ versus bulk density $\left(\rho_{\mathrm{b}}\right)$ crossplot of A8 well

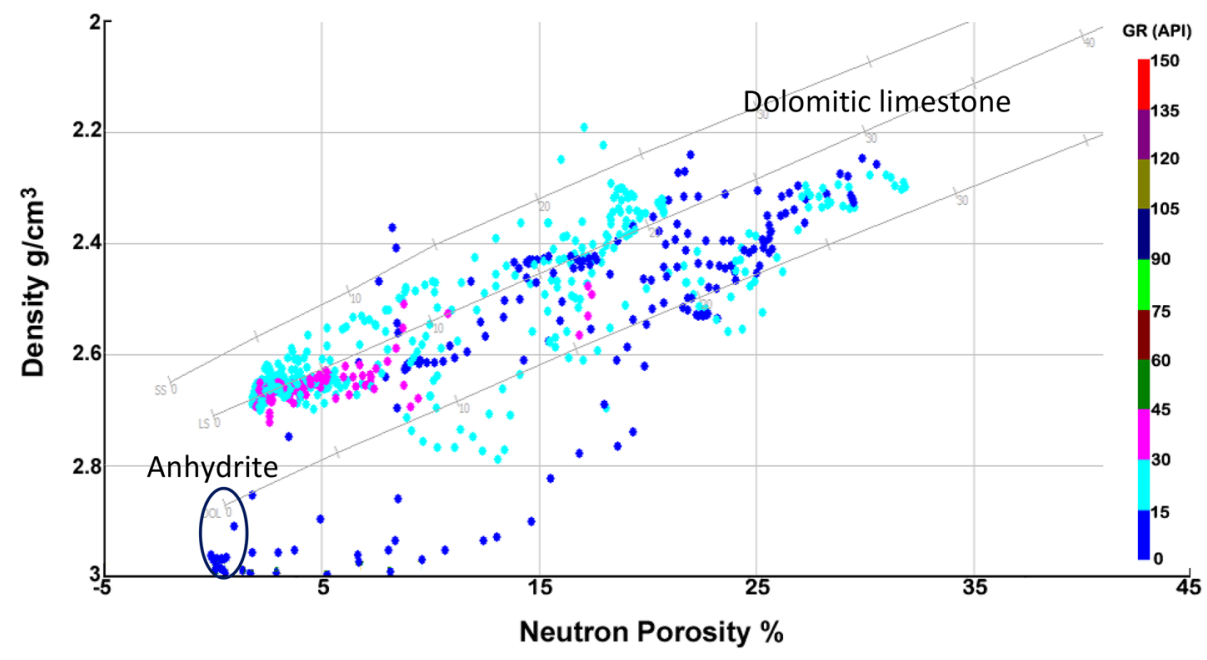

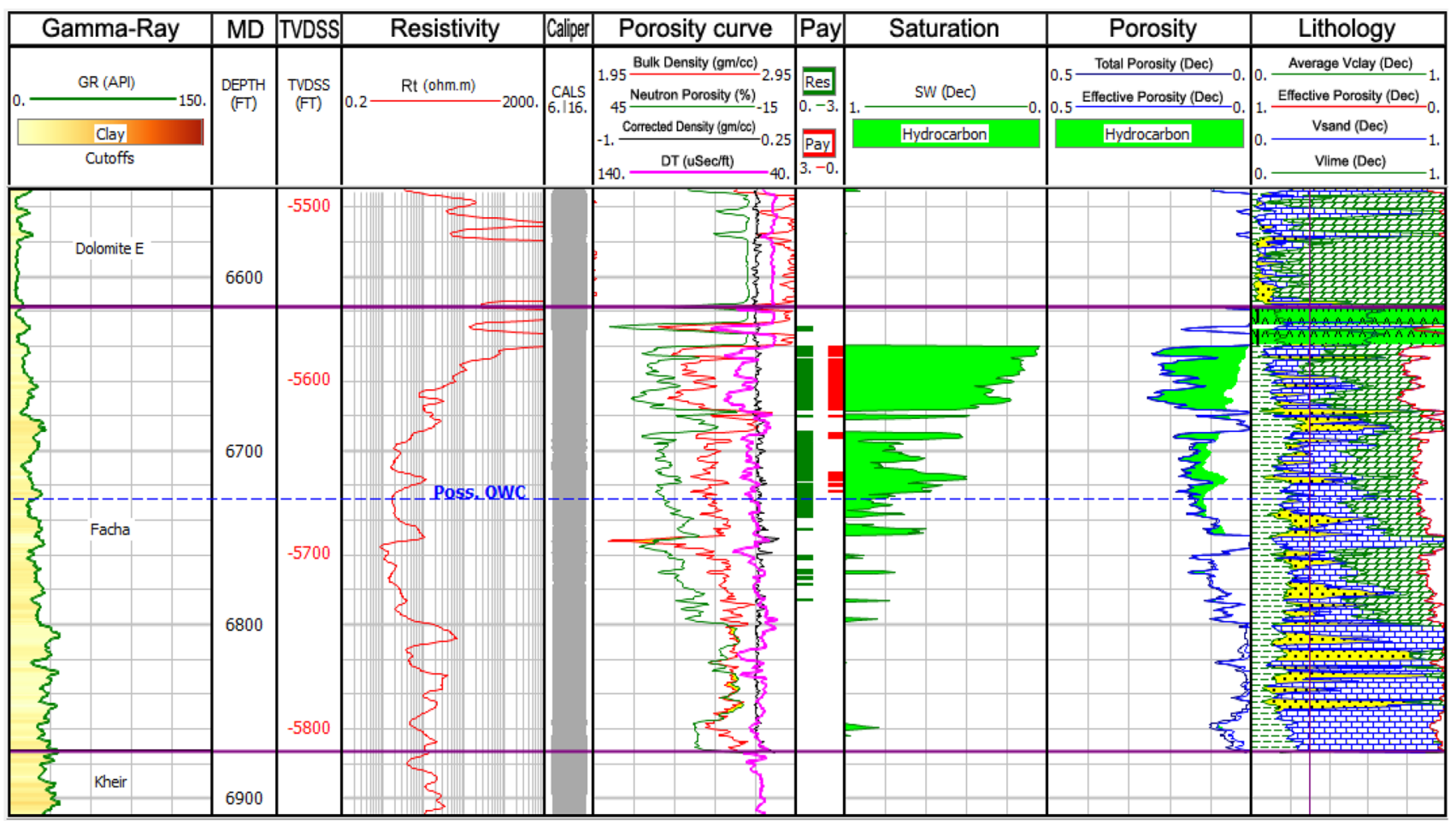

Fig. 9 Litho-saturation log plot of A1 well (as example), Facha reservoir

are located at low structure of the field, show a decrease in hydrocarbon content (Fig. 10).

The possible oil-water contact was defined on the log plot roughly within the Facha reservoir and above the highly water saturated interval for all the studied wells. The depth of this contact is dependent on the depth of the reservoir, determined at remarkably different total vertical depths subsea "TVDSS" for A1 and A13 wells ( $\approx 5670 \mathrm{ft}$ and $5840 \mathrm{ft}$, respectively). It is noteworthy that the two litho-saturation log plots (Figs. 8, 9) are examples of wells located at high structure and low structure (A1 and A13, respectively) (Fig. 11).

\section{Determination of cutoff values}

The effective porosity versus shale content and effective porosity versus effective water saturation cross-plots, derived from logging data, in conjunction with gamma ray log readings plotted on the $z$ axis (Teama and Nabawy 2016; and El-Din et al. 2013) of the Facha reservoir were utilized 


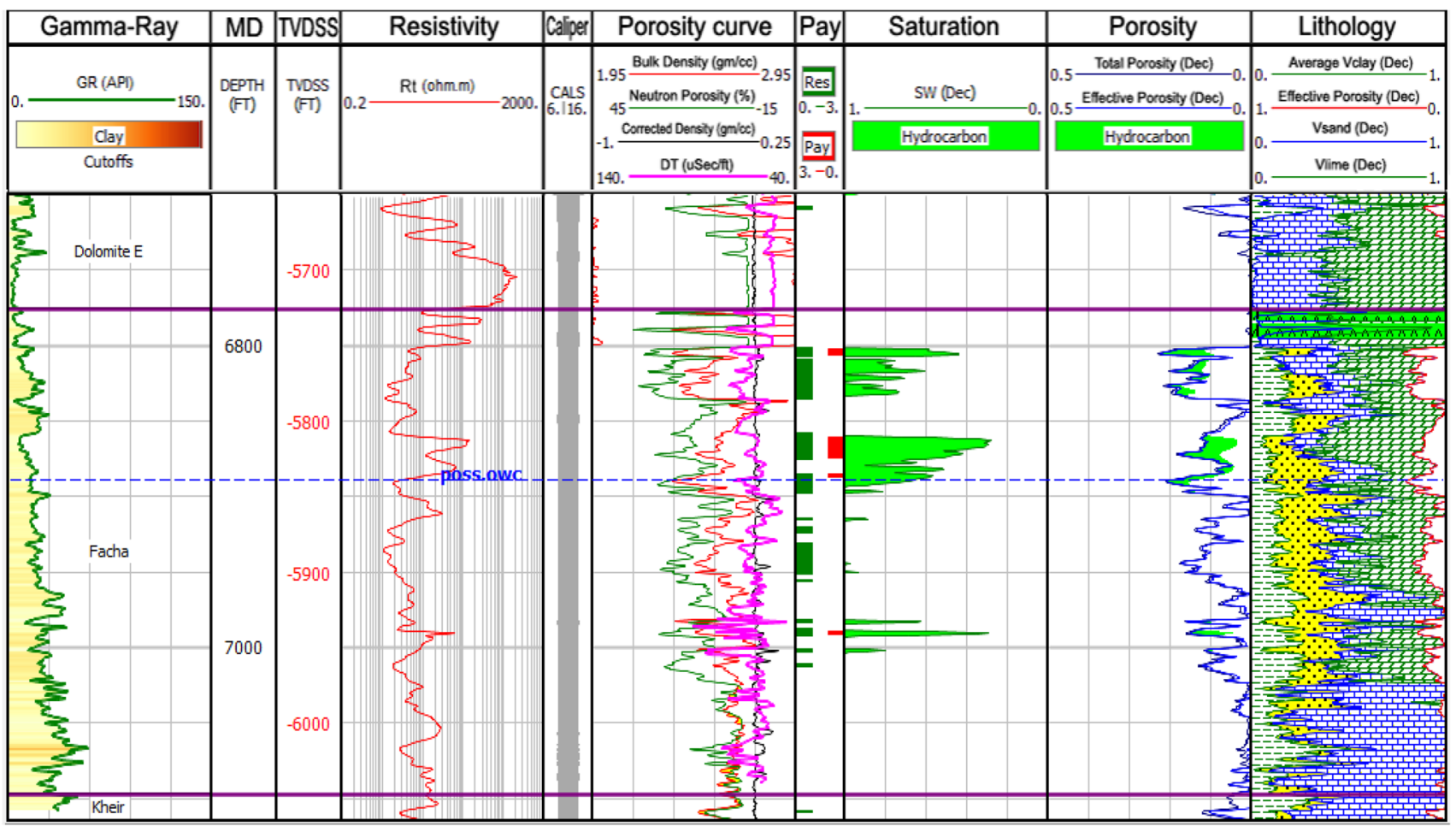

Fig. 10 Litho-saturation log plot of A13 well (as example), Facha reservoir

Fig. 11 Structure contour map of the Facha reservoir

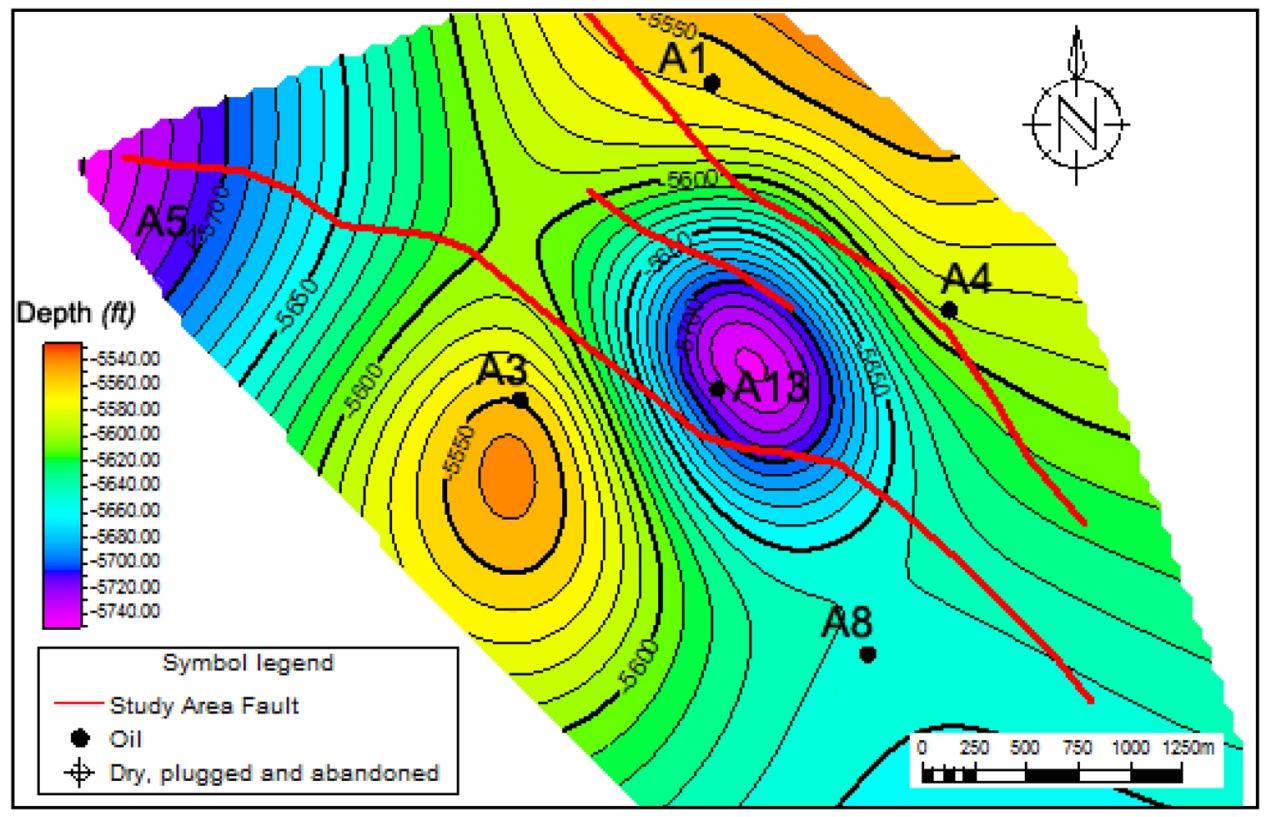

In conclusion, most of the net pay productive reservoir intervals (porous intervals) are characterized by an effective porosity values greater than $10 \%$, a shale content values less than $20 \%$ and a water saturation values less than $70 \%$. 

content as a function in porosity accompanied with the gamma ray scale for cutoff determination
Fig. 12 Cross-plot of the shale

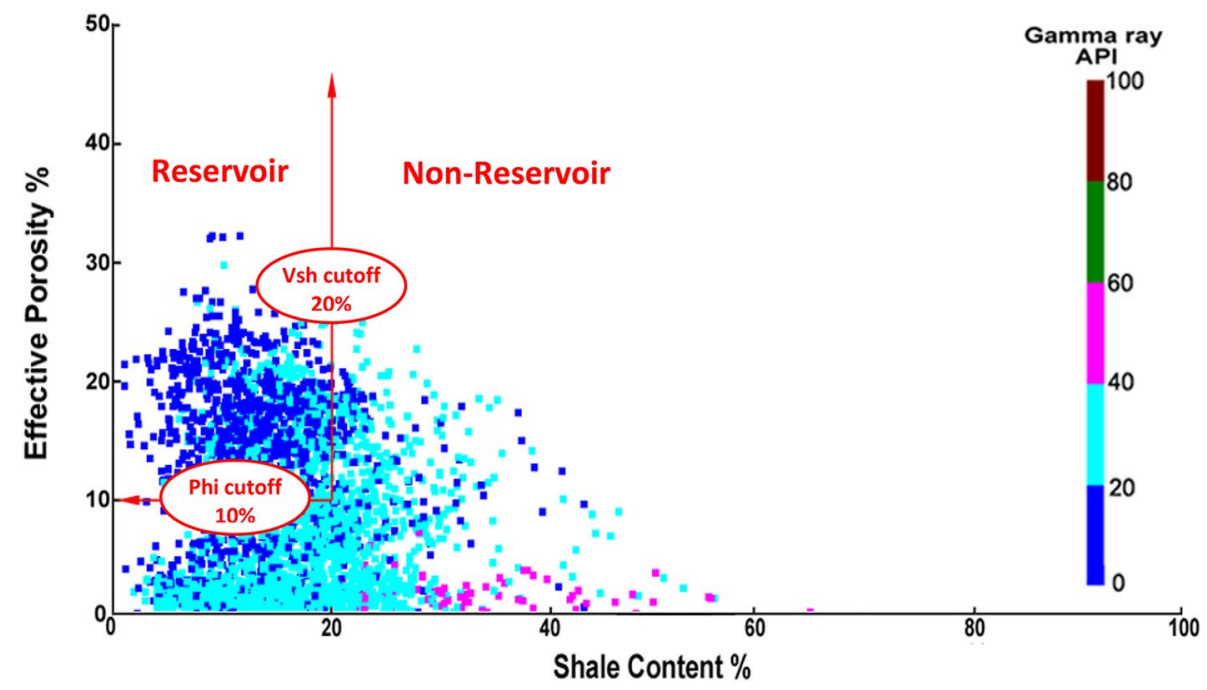

Fig. 13 Effective porosity-water saturation cross-plot accompanied with the gamma ray scale for cutoff determination

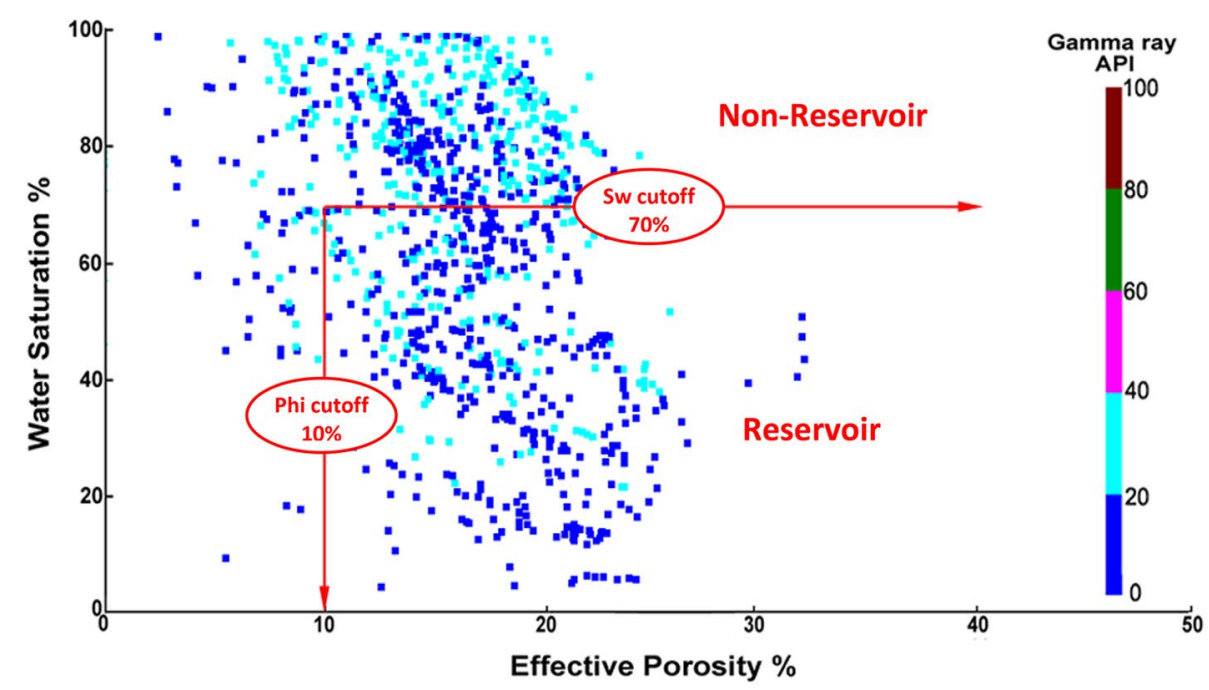

Table 1 Reservoir parameters of the Facha reservoir

\begin{tabular}{llllllll}
\hline Well name Strata & Top depth $(\mathrm{ft})$ & $\begin{array}{l}\text { Bottom } \\
\text { depth } \\
(\mathrm{ft})\end{array}$ & $\begin{array}{l}\text { Total } \\
\text { thickness } \\
(\mathrm{ft})\end{array}$ & $\begin{array}{l}\text { Average } \\
\text { porosity } \\
(\%)\end{array}$ & $\begin{array}{l}\text { Average water } \\
\text { saturation }(\%)\end{array}$ & $\begin{array}{l}\text { Average } \\
\text { Shale content } \\
(\%)\end{array}$ & $\begin{array}{l}\text { Net pay } \\
\text { thickness } \\
(\mathrm{ft})\end{array}$ \\
\hline A1 & Facha Formation (Lower Eocene) & 6617 & 6940 & 323 & 15.9 & 48.8 & 11.5 \\
A3 & & 6572 & 6903 & 331 & 17.6 & 64.9 & 48 \\
A4 & & 6676 & 6856 & 180 & 15.3 & 74.9 & 11.3 \\
A5 & 6706 & 7025 & 319 & 16.9 & 89.2 & 12.7 & 32 \\
A8 & 6684 & 7014 & 330 & 17.3 & 62 & 0 \\
A13 & 6775 & 7097 & 322 & 14 & 77.6 & 9.9 & 5.9 \\
\hline
\end{tabular}

\section{Formation evaluation}

The petrophysical parameters of the studied reservoir have been driven from six wells (A1, A3, A4, A5, A8 and A13). The results are summarized in Table 1 and represented by different maps of reservoir characteristics in the Hakim Oil Field.

The contour maps for the acquired results were prepared using Petrel (2013) Schlumberger software to reflect the general distribution throughout the Facha reservoir. 
Fig. 14 Average shale content $\left(V_{\mathrm{sh}}\right)$ in the Facha reservoir in the study area

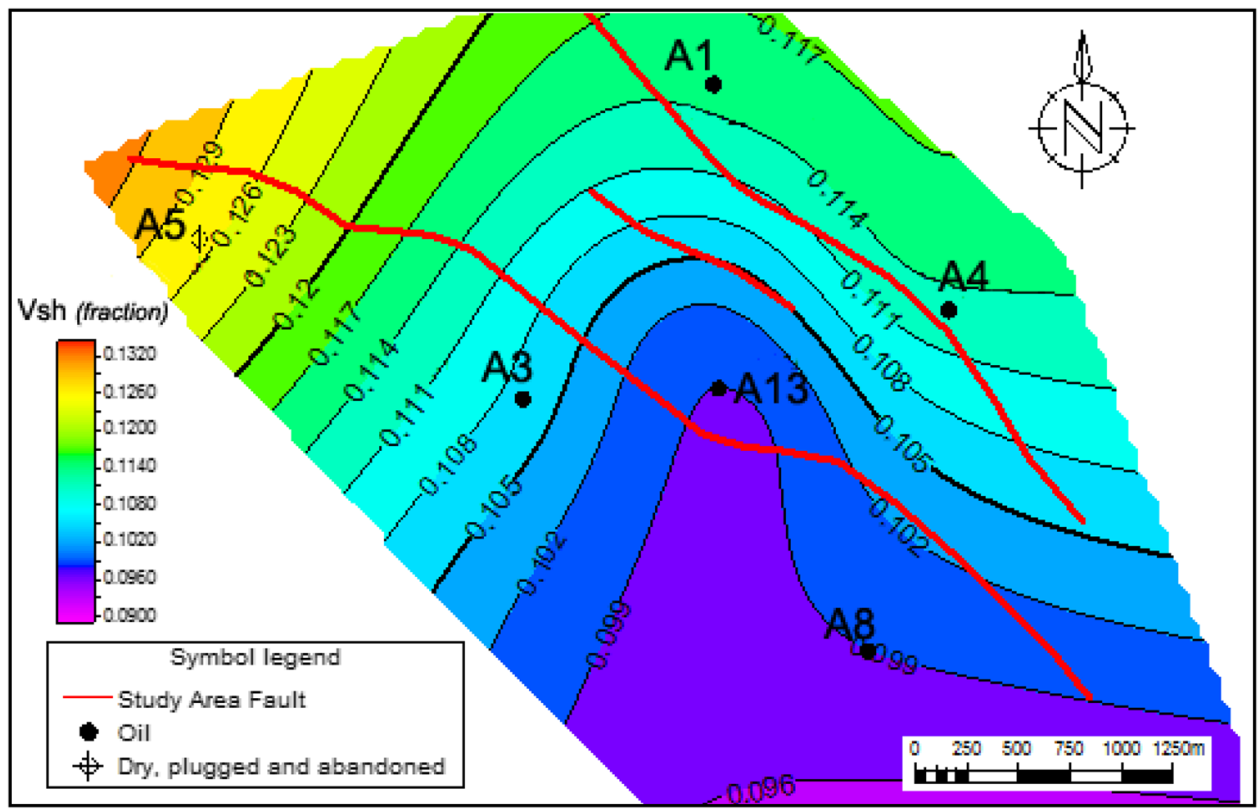

\section{Contour map of shale content}

By applying gamma ray and neutron-density records, the volume of shale was calculated. The shale volume ranges from 9.9 to $12.7 \%$ representing a clean reservoir. However, Fig. 14 shows that the shale content of the reservoir tends to increase relatively toward the northwestern part of the study area.

\section{Water saturation contour map}

According to the obtained results, the $S_{\mathrm{w}}$ values (Fig. 15) show that the water content within the reservoir decreases in both northeastern and southern parts of the area of investigation, where the A1 well has the minimum value of $S_{\mathrm{w}}$ with $48.8 \%$. On the other hand, in the central and northwestern parts, the values increase, where they reached to a maximum value at A5 well with $89.2 \%$ of $S_{\mathrm{w}}$, which means that the A5 well can be considered as a dry hole.
Fig. 15 Average water saturation $\left(S_{\mathrm{w}}\right)$ of the Facha reservoir in the study area

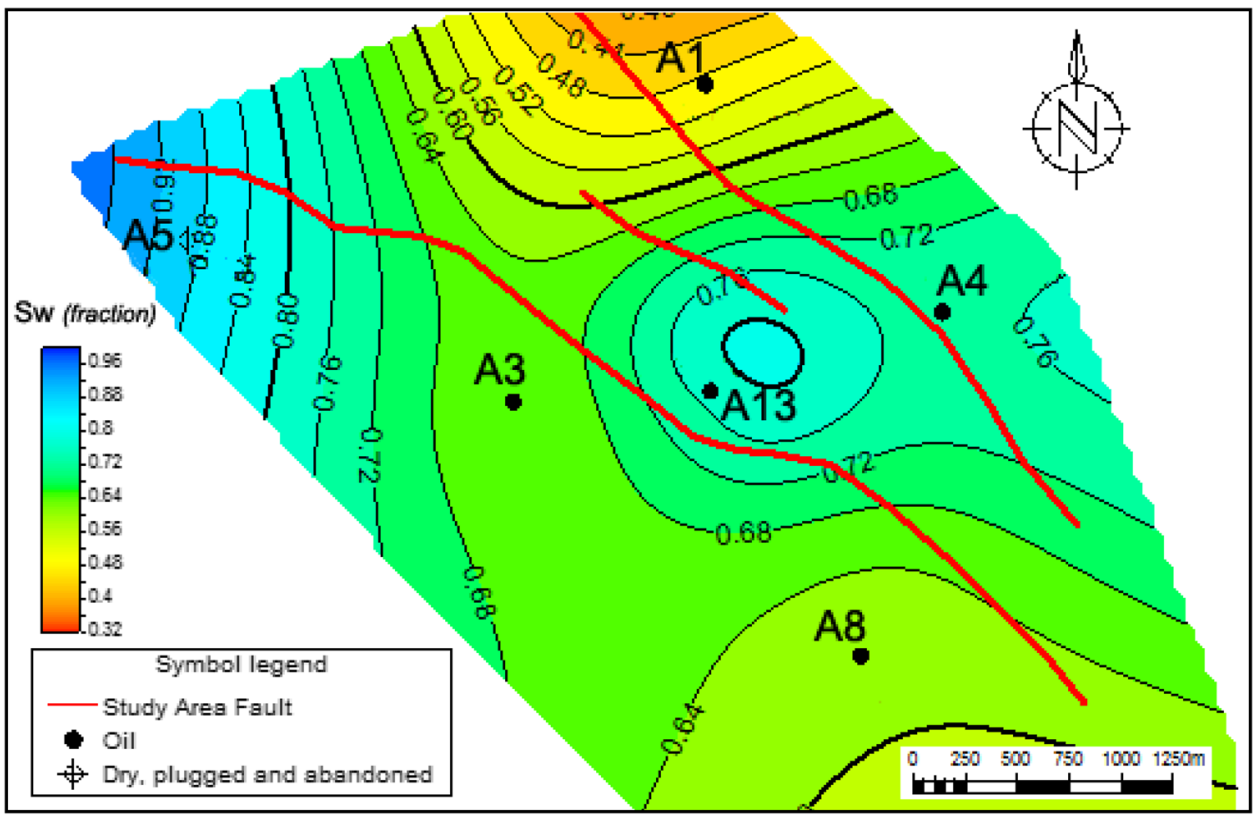


Fig. 16 Average porosity values $(\Phi)$ of the Facha reservoir in the study area

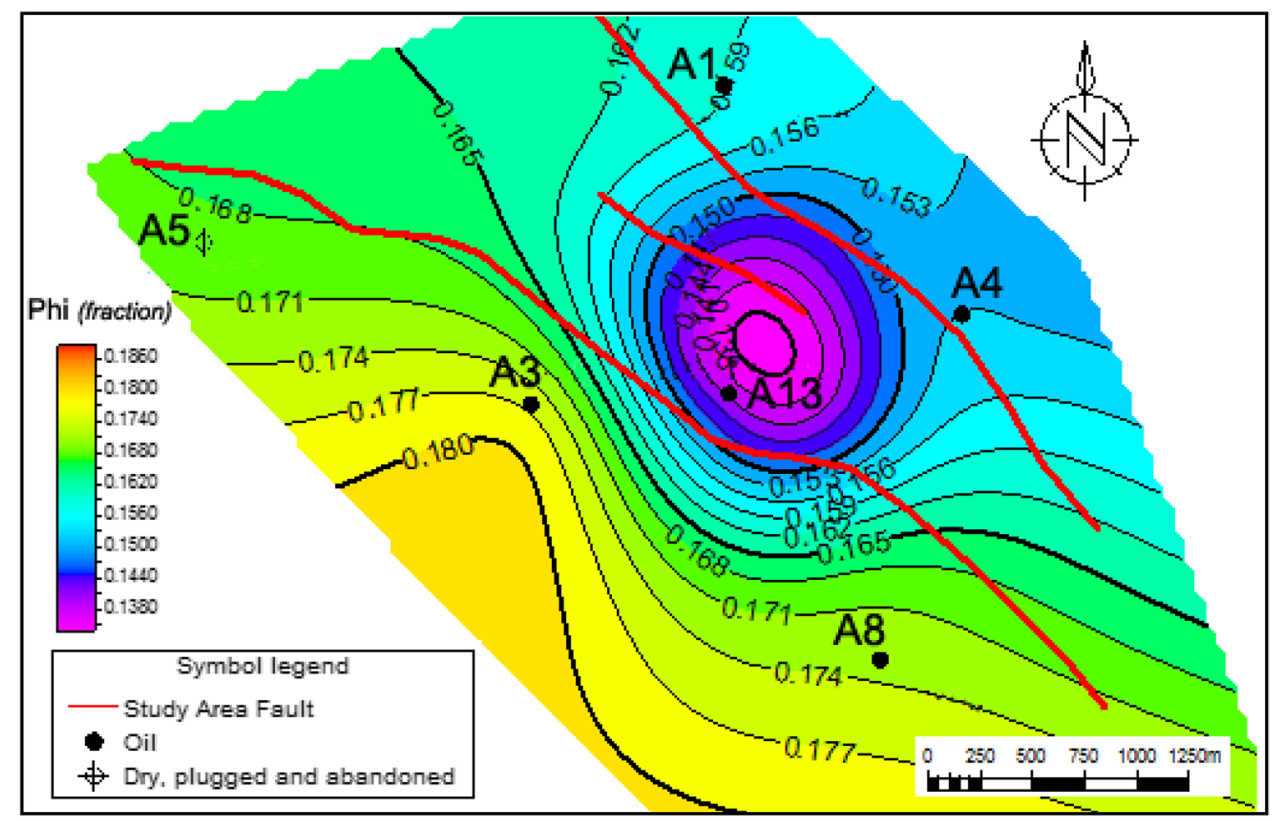

\section{Contour map of average porosity}

Porosity distribution of Facha reservoir is shown by Fig. 16 . This map shows that the reservoir is characterized by its good porosity character. The minimum value reached at the central part of the study area, where it has a value of $14 \%$ at A13 well, whereas the rest of area shows good values of porosity, with a maximum value of $17 \%$ at $\mathrm{A} 3$ well at the eastern part of the study area.

\section{Contour map of net pay thickness}

The net reservoir thickness of Facha reservoir ranges from $96.50 \mathrm{ft}$ at A1 well to $130.50 \mathrm{ft}$ at A5 well and was calculated according to the cutoff values. However, the pay thickness ranges from $0 \mathrm{ft}$ at $\mathrm{A} 5$ well to $53.5 \mathrm{ft}$ at $\mathrm{A} 8$ well, which implies that the south and north of the study area have a tendency to have more amounts of recoverable hydrocarbons (Fig. 17).
Fig. 17 Average net pay thickness of the Facha reservoir in the study area

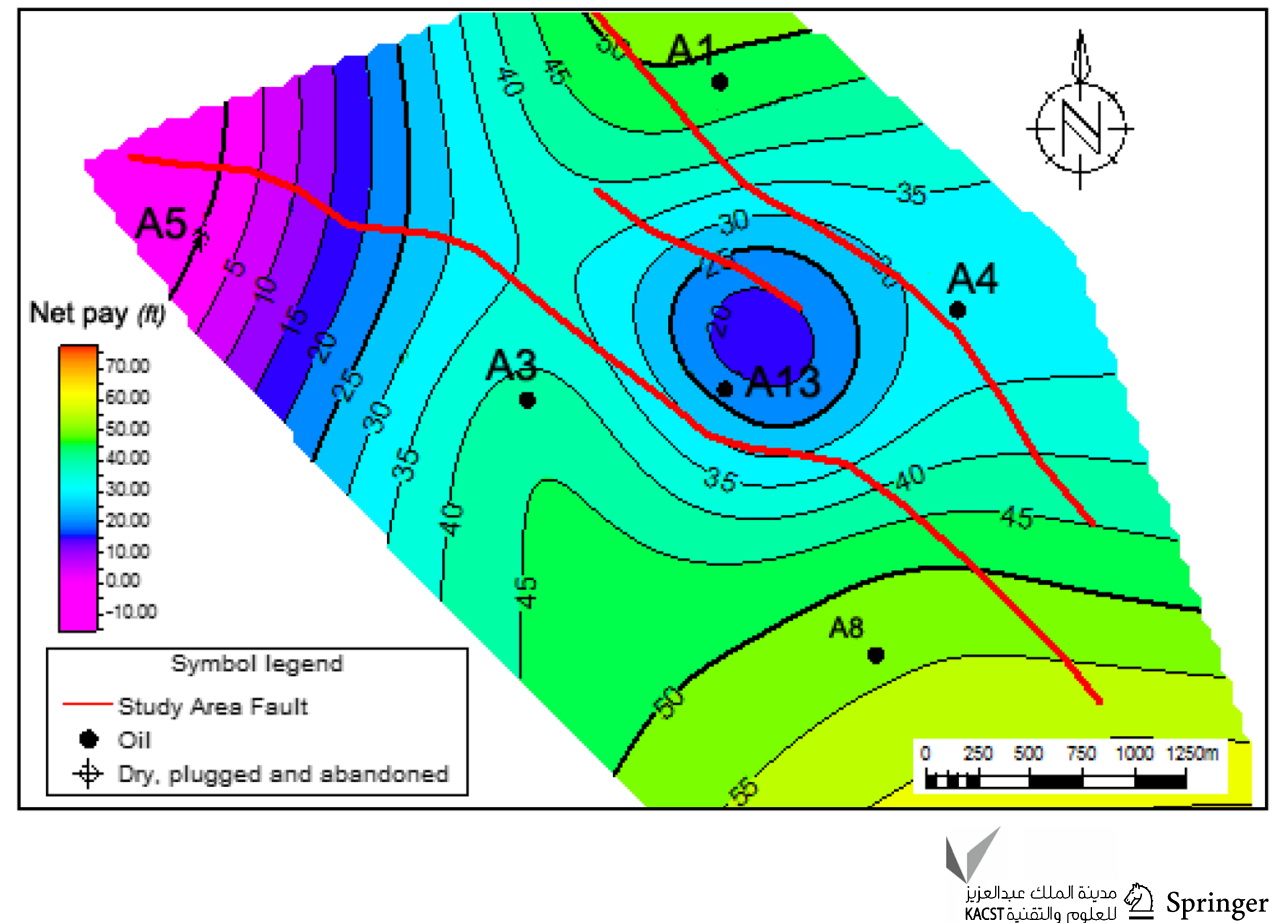




\section{Conclusions}

The study of petrophysical characteristics and evaluation of hydrocarbon potentiality of the Lower Eocene Facha reservoir were established based on geological information and the results obtained from well log analysis in Hakim Oil Field.

We concluded from cross-plot analysis that the lithology of the Facha reservoir varies from calcareous dolostone in A1, A5 and A13 wells with an increase in clay content in A1 and A5 wells, limestone in A3 well with slightly increase in clay content, dolostone in A4 well with an increase in clay content, and dolomitic limestone in A8 well with less clay content. The Facha reservoir in all wells includes few anhydrite interbeds with an increase in limestones in the lower parts.

The structural settings might play an important role in change of pay thickness and effective porosity, rather than change in facies.

The multi-well cross-plot of shale content versus effective porosity cross-plot and gamma ray scale, in addition to, water saturation versus effective porosity cross-plot accompanied also by gamma ray scale were used to define the different required cutoffs to discriminate between reservoir and non-reservoir intervals. The cutoff values of the effective pays were determined as $20 \%$ for shale content, $10 \%$ for porosity and $70 \%$ for water saturation.

Contour maps of water saturation, porosity and net pay thickness show that the Facha reservoir has good petrophysical properties, especially in south and north of the study area and is favorable for oil accumulation.

Acknowledgements The authors would like to thank Zueitina oil company, Libya, for supplying the required data for this study. Also, they would like to express their deep gratitude and sincere appreciation to Eng. Mohammed El-Gheriani and Hussein Ben-Dalah for their support during this work and to Eng. Bahiya Ghawwar for the great effort and her stimulating guidance.

\section{Compliance with ethical standards}

Conflict of interest On behalf of all authors, the corresponding author states that there is no conflict of interest.

Open Access This article is distributed under the terms of the Creative Commons Attribution 4.0 International License (http://creativeco mmons.org/licenses/by/4.0/), which permits unrestricted use, distribution, and reproduction in any medium, provided you give appropriate credit to the original author(s) and the source, provide a link to the Creative Commons license, and indicate if changes were made.

\section{References}

Abadi A (2002) Tectonics of the Sirte basin. Ph.D. Dissertation, Vrije Universiteit, Amsterdam, ITC, Enschede, p 187
Aboglila S, Elkhalgi M (2013) Organic geochemical evaluation of cretaceous potential source rocks, East Sirte basin, Libya. Int J Geosci 4(4):11

Ahlbrandt TS (2001) The Sirte basin Province of Libya: Sirte-Zelten total petroleum system. US Department of the Interior, US Geological Survey Bulletin 2202-F

Ambrose G (2000) The geology and hydrocarbon habitat of the Sarir Sandstone, SE Sirte basin, Libya. J Pet Geol 23:165-192

Archie GE (1942) The electrical resistivity log as an aid in determining some reservoir characteristics. Trans AIME 146:54-64

Asquith G (1982) Basic well log analysis for geologists, pub by the American association of petroleum geologists, Tulsa, Oklahoma, USA, p 216

Barr FT, Weeger AA (1972) Stratigraphic Nomenclature of the Sirte basin, Libya. Petroleum Exploration Society of Libya, Tripoli, $179 \mathrm{p}$

Burwood R (1997) Petroleum systems of the East Sirte basin. Am Assoc Pet Geol Bull 81:1365

EL-Alami M, Rahouma S, Butt AA (1989) Hydrocarbon habitat in the Sirte basin Northern Libya. Pet Res J Tripoli 1:17-28

El-Din ES, Mesbah MA, Kassab MA, Mohamed IF, Cheadle BA, Teama MA (2013) Assessment of petrophysical parameters of clastics using well logs: the Upper Miocene in El-Wastani gas field, onshore Nile Delta, Egypt. J Pet Explor Dev PetroChina 40(4):488-494

El-Khadragy AA, Shazly TF, Ramadan M, El-Sawy MZ (2017) Petrophysical investigations to both Rudeis and Kareem formations, Ras Ghara oil field, Gulf of Suez, Egypt. Egypt J Pet 26:269-277

Futyan A, Jawzi AH (1996) The hydrocarbon habitat of the oil and gas fields of North Africa with emphasis on the Sirte basin. In: Salem MJ, El-Hawat AS, Sbeta AM (eds) The geology of Sirte basin, vol 2. Elsevier, Amsterdam, pp 287-308

Geological Review of Hakim (1981) Zuetionah Oil Company Field. Unpublished report

Ghori KAR, Mohammed RA (1996) The application of petroleum generation modeling to the Eastern Sirte basin, Libya. In: Salem MJ, El-Hawat AS, Sbeta AM (eds) The geology of Sirte basin, vol 2. Elsevier, Amsterdam, pp 529-540

Guiraud R, Bosworth W (1997) Senonian basin inversion and rejuvenation of rifting in Africa and Arabia-synthesis and implication to plate-scale tectonics. Tectonophysics 282:39-82

Gumati YD, Schamel S (1988) Thermal maturation history of the Sirte basin, Libya. J Pet Geol 11:205-218

Hallet D (2002) Petroleum geology of Libya. Elsevier Science Limited, Kidlington

Harding TP (1984) Graben hydrocarbon occurrences and structural styles. Am Assoc Pet Geol Bull 68:333-362

Macgregor DS, Moody RTJ (1998) Mesozoic and cenozoic petroleum systems of North Africa. In: Moody RTJ, Clark-Lowes DD, Macgregor DS (eds) Petroleum geology of North Africa, vol 132. Geological Society, Special Publication, London, pp 201-216

Montgomery S (1994) Sirte basin, north-central Libya, Prospects for the Future. Pet Front 11(1):94

Parsons MB, Azgaar AM, Curry JJ (1980) Hydrocarbon occurrences in the Sirte basin, Libya. In: Miall AD (ed) Canadian Society Petroleum Geologists Memoir, vol 6, pp 723-732

Teama MA, Nabawy BS (2016) Petrophysical evaluation of the hydrocarbon potential of the lower cretaceous Kharita clastics, North Qarun oil field, Western Desert, Egypt. J Afr Earth Sci 121:62-71

Van der Meer JJ (1993) Microscopic evidence of sub-glacial deformation. Quatern Sci Rev 12(7):553-587

Publisher's Note Springer Nature remains neutral with regard to jurisdictional claims in published maps and institutional affiliations. 